\title{
Irrigation water consumption modelling of a soilless cucumber crop under specific greenhouse conditions in a humid tropical climate
}

\author{
Galo Alberto Salcedo ${ }^{1}$ Juan Reca ${ }^{2}$ \\ Mónica Pérez-Sáiz ${ }^{3}$ María Teresa $\mathbf{L a o}^{3}$
}

\begin{abstract}
${ }^{1}$ School of Sciences for the Development, University of Guayaquil, Ecuador.
${ }^{2}$ Departament of Engineering, University of Almería, CITE II-A, 1.11. La Cañada de S. Urbano, 04120- Almería, Campus of International Excellence in Agrifood (CeiA3), Ecuador. E-mail: jreca@ual.es. Corresponding author.

${ }^{3}$ Departament of Agronomy, University of Almería, Escuela Superior de Ingeniería, La Cañada de S. Urbano, Campus of International Excellence in Agrifood (CeiA3), Ecuador.
\end{abstract}

\begin{abstract}
The irrigation water consumption of a soilless cucumber crop under greenhouse conditions in a humid tropical climate has been evaluated in this paper in order to improve the irrigation water and fertilizers management in these specific conditions. For this purpose, a field experiment was conducted. Two trials were carried out during the years 2011 and 2014 in an experimental farm located in Vinces (Ecuador). In each trial, the complete growing cycle of a cucumber crop grown under a greenhouse was evaluated. Crop development was monitored and a good fit to a sigmoidal Gompertz type growth function was reported. The daily water uptake of the crop was measured and related to the most relevant indoor climate variables. Two different combination methods, namely the Penman-Monteith equation and the Baille equation, were applied. However, the results obtained with these combination methods were not satisfactory due to the poor correlation between the climatic variables, especially the incoming radiation, and the crop's water uptake (WU). On contrary, a good correlation was reported between the crop's water uptake and the leaf area index (LAI), especially in the initial crop stages. However, when the crop is fully developed, the WU stabilizes and becomes independent from the LAI. A preliminary model to simulate the water uptake of the crop was adjusted using the data obtained in the first experiment and then validated with the data of the second experiment.
\end{abstract}

Key words: Cucumis sativus, greenhouse, soilless crops, water consumption, tropical climate.

Modelação de consumo de água de irrigação de pepino sem solo em condições específicas de uma casa de vegetação em um clima tropical húmido

RESUMO: Com o objetivo de melhorar a gestão da água de irrigação e fertilizantes em condições específicas, foi avaliado, neste trabalho, o consumo de água de irrigação de pepinos cultivados sem solo em casa de vegetação. Para avaliar este efeito, conduziu-se um experimento de campo. O trabalho de pesquisa foi composto de dois ensaios realizados durante os anos de 2011 e 2014 em Vinces (Equador), onde predomina o clima tropical. Em cada ensaio, avaliou-se o ciclo de crescimento completo da cultura do pepino cultivada em estufa.O desenvolvimento da cultura foi monitorado e um bom ajuste para a função de crescimento tipo sigmoidal Gompertz foi encontrado. A absorção de água diária da cultura foi medida e relacionada às variáveis climáticas mais relevantes. Com o objetivo de modelar o consumo de água das culturas, dois métodos de combinação diferentes, isto é, a equação de Penman-Monteith e a equação Baille, foram aplicadas. No entanto, os resultados obtidos com estes métodos de combinação não foram satisfatórios devido a fraca correlação entre as variáveis climáticas, especialmente, a radiação incidente e absorção de água pela cultura (WU). Por outro lado, foi encontrada uma boa correlação entre a captação de água da cultura e o indice de área foliar (LAI), especialmente, nos estágios iniciais da cultura. No entanto, quando a cultura está completamente desenvolvida, o WU estabiliza e torna-se independente do LAI. Um modelo preliminar para simular a absorção de água da cultura foi ajustado e utilizado e, os dados obtidos do primeiro experimento foram comparados com os dados do segundo.

Palavras-chave: pepino, estufa, cultivo sem solo, consumo de água, clima tropical.

\section{INTRODUCTION}

Although the major and most profitable crops in tropical countries in South America, such as Ecuador, are banana and cocoa, the horticultural production can be a complementary sector that can contribute decisively to the food security and economic development of the region (INEC, 2014). However, the development of the horticulture in these regions has to face some limiting factors such as the high amount of precipitation that can produce damage to the 
crop, flooding of the soils and fields and the high risk of pest and disease incidents. Soilless culture under greenhouses is a promising alternative in these regions that could avoid most of these drawbacks. Cucumber and other cucurbits have been successfully cultivated both in soilless and on hydroponics solutions (COSTA et al. (2001), SHAW \& CANTLIFFE (2005). There are important differences both in the design and the covering materials between tropical greenhouses and those existing in Mediterranean or other colder climates. While in the latter cases, the main purpose of the greenhouse is to collect solar energy in order to heat up the greenhouse and maintain indoors temperatures within an optimum range, in tropical greenhouses, the aim is to evacuate the heat excess from the greenhouse as they are designed not to maintain indoors temperatures but to protect the crop from the rain, pests and diseases. Nevertheless, since the protected agriculture development in tropical regions is currently very limited, there is a lack of specific information regarding the crop's water requirements and there is a need to establish accurate enough but simple and low cost methods for the optimal irrigation management under these conditions.

Although many studies to model the water requirements of different types of crops under greenhouse conditions have been conducted (STANGHELLINI, 1987; JOLLIET \& BAILEY, 1992; YAGHI et al., 2013), most of them have been carried out in climatic conditions that greatly differ from those taking place in tropical climates. In addition, in soilless culture, root volume is small and the amount of available water for the plant is low, so mistakes in the water application cannot be buffered by the system.

Among the methods proposed by the Food and Agriculture Organization of the United Nations (FAO) (ALLEN et al., 1998) in order to determine reference evapotranspiration, the most commonly used to calculate transpiration of crops in greenhouse conditions are the PenmanMonteith method and the pan evaporation methods. The approach proposed by Penman-Monteith has been applied to greenhouse conditions by STANGHELLINI (1987), JOLLIET \& BAILEY (1992), BAILEY et al. (1993), BAKKER (1991) and BAILLE et al. (1994b) among others. The Penman-Monteith method estimates the reference evapotranspiration $\left(E T_{0}\right)$ with a fairly high precision under plastic greenhouses in Mediterranean conditions (FERNÁNDEZ et al. 2010). These authors also concluded that the solar radiation was the main factor affecting the $E T_{0}$ and developed a radiation method for the estimation of greenhouse $E T_{0}$, which was locally calibrated and performed correctly under different conditions. Another simplified combined method widely accepted for the estimation of the hourly transpiration rate under greenhouse climatic conditions is the one proposed by BAILLE et al. (1994a). This method has been successfully applied to rose (KATSOULAS et al., 2001) and ornamentals (BAILLE et al., 1994b).

The objective of this research is to evaluate experimentally the crop's water uptake of a soilless cucumber crop planted under greenhouse conditions in a tropical climate as well as to improve our understanding and to model this process under these specific conditions. To achieve this objective, an experimental test on a soilless cucumber crop grown under a greenhouse in the specific tropical conditions of the province of "Los Rios" in Ecuador was carried out.

\section{MATERIALS AND METHODS}

This research was conducted in a experimental greenhouse farm belonging to the University of Guayaquil and located in the municipality of Vinces (province of "Los Ríos" in Ecuador) at the Geographical coordinates -1.5604 and -79.7669 (WGS 84). Its elevation is 41 meters above the sea level. The area has a tropical humid climate, with a high average annual precipitation $\left(1492 \mathrm{~mm} \mathrm{year}^{-1}\right)$ and relative humidity $(83 \%)$. Estimated annual evaporation is about $1000 \mathrm{~mm}$ year $^{-1}$. Winds are smooth; the average air speed is $1.3 \mathrm{~m} \mathrm{~s}^{-1}$. The sky is usually cloudy and there are 1943 sunlight hours per year in average. The weather is warm with an average annual temperature of $25^{\circ} \mathrm{C}$.

The experiment was carried out in a multispan greenhouse with 5 spans, 8 meters wide each. Greenhouse was covered with a thermal multilayer co-extrusion film of $200 \mu \mathrm{m}$ width, with $50 \%$ total transmission of light and $60 \%$ radiation diffusion. The front and back walls were covered with an anti-pest mesh. The greenhouse structure had relatively little influence on the 
climate conditions inside the greenhouse, except in the case of the incoming radiation due to the effect of the low transmission of radiation of the thermal plastic film used in this experiment. Average temperature was $24.3^{\circ} \mathrm{C}$ inside the greenhouse whereas it was $25.3^{\circ} \mathrm{C}$ outside. The same thing happened with the relative humidity (71 and $72.5 \%$, respectively).

A cucumber crop (Cucumis sativus L. cv. 'Diamante') was planted with a plant density of 1.33 plants $\mathrm{m}^{-2}\left(1.50 \mathrm{x} 0.50 \mathrm{~m}^{-2}\right)$. Plants were sowed in gutters covered by a white plastic film of $200 \mu \mathrm{m}, 27 \mathrm{~m}$ long and $0.40 \mathrm{~m}$ wide. The substrate consisted of burnt rice husk at a rate of $70 \%$ as it is a low cost, highly available and sustainable local product. Nutrient solution used was that proposed by VASCO (2003).

Two field experiments were conducted. The first essay was conducted during 2011 and it lasted from October $3^{\text {rd }}$ to November $25^{\text {th }}$, whereas the second field experiment was conducted during the year 2014, from January $29^{\text {th }}$ to March $21^{\text {st }}$. Data provided by the first experiment were used to develop and calibrate the irrigation water uptake model whereas the second experiment was used to test and validate it.

Experimental design and measurements:

a) Climatic conditions: climatic data were obtained from two weather stations provided by Campbell Scientific installed both inside and outside the experimental greenhouse. The following variables were monitored: incoming solar radiation $\left(\mathrm{W} \mathrm{m}^{-2}\right)$, air temperature $\left({ }^{\circ} \mathrm{C}\right)$, relative humidity $(\%)$ and wind speed $\left(\mathrm{m} \mathrm{s}^{-1}\right)$. In addition, rainfall was also measured outdoors with a rain gauge.

b) Water uptake: daily measurements of the irrigation and the drainage water volumes were conducted. The drainage water from the gutters was collected in an underground tank made of concrete through a network of buried pipe drains. The water collected in the tank was measured volumetrically. The daily water uptake of the crop was calculated by applying a water balance.

c) Leaf area and Leaf area Index: leaf area $(L A)$ measurements were carried out for every crop development stage. The $L A$ was estimated using a non-destructive method based on the measurement of the leaf length and width of all the leaves of each plant in a sample of 36 random plants. rRelationship between the leaf area and the dimensions of the leaves proposed by MEDRANO (2005) was used in this research (see Equation 1):

$L A=0.8405 \cdot L \cdot W$

where: $L$ and $W$ are the length and width of the leaf respectively and $L A$ is the leaf area.

The leaf area index ( $L A I)$ was obtained as a function of the average $L A$ and the plant density.

The knowledge on the development of the canopy is essential in order to model the transpiration of the crop as it determines both the amount of radiation intercepted by the crop and the water vapor exchange between the plant and the atmosphere. Different crop growth curves have been proposed in the literature. Exponential functions were suggested in some research (HSIAO et al. 2007; CONFALONE et al., 2010; STEDUTO et al., 2012). In Mediterranean greenhouse crops, conversely, sigmoid curves have been applied to model the $L A I$ as a function the cumulative thermal time (CTT) (MEDRANO et al., 2005; ORGAZ et al. 2005; CARMASSI et al., 2007). In this work, a sigmoid Gompertz function (GOMPERTZ, 1832) has been used. The Gompertz function was adjusted with the data obtained in the experiment carried out in 2011 and then it was validated in the experiment conducted in 2014.

The plant's water uptake $(W U)$ is mainly due to the transpiration of the crop. Water uptake $(W U)$ and the crop transpiration $\left(T_{c}\right)$ are the same, provided that the constitutional water is neglected. $T$ is also equivalent to the crop evapotranspiration $\left(E T_{c}\right)$ as the evaporation from the substrate can be neglected because it was covered by plastic mulch. Two different combination methods were tested in this research in order to model the crop water uptake.

The methodology proposed by FAO (ALLEN et al., 1998) to calculate crop evapotranspiration is based on considering separately the effects of the climate (reference evapotranspiration) and the plant canopy (crop coefficient, $K_{c}$ ) on the crop's water consumption. The crop's evapotranspiration is thus calculated by the following equation:

$E T_{C}=E T_{o} \cdot K_{C}$ where: $E T_{c}$ and $E T_{o}$ are the crop and reference evapotranspiration (in $\mathrm{mm}$ ), respectively. 
The FAO Irrigation and Drainage paper No. 56 recommends the Penman-Monteith equation as the standard method to calculate $E T_{o}$ (Equations 3 and 4)

$$
\begin{aligned}
E T_{0} & =\frac{\Delta}{\Delta+\gamma^{*}} R_{n}+\frac{\rho_{a} c_{p}}{\left(\Delta+\gamma^{*}\right) r_{a}} V P D \\
\gamma^{*} & =\gamma\left(1+\frac{r_{c}}{r_{a}}\right)
\end{aligned}
$$

where: $R_{n}$ is the net radiation, $V P D$ is the vapour pressure deficit, $\rho_{a}$ is the average air density at a constant pressure, $c_{p}$ is the specific heat of the air, $\Delta$ represents the slope of the saturation vapour pressure temperature curve, $\gamma$ is the psychrometric constant, and $r_{c}$ and $r_{a}$ are the (bulk) surface and aerodynamic resistances.

BAILLE et al. (1994a, b) proposed a simplified combined method (See Equation 5):

\section{$T=A \cdot f_{I}(L A I) \cdot R+B \cdot L A I \cdot V P D$}

where: $T\left(\mathrm{~mm} \mathrm{day}^{-1}\right)$ is the crop transpiration, $R$ is the solar radiation (mm day $\left.{ }^{-1}\right), A$ and $B\left(\mathrm{~mm} \mathrm{day}^{-1} \mathrm{kPa}^{-1}\right)$ are both crop coefficients, which must be determined experimentally for each crop. $f_{l}$ is a dimensionless exponential function that considers the interception of the radiation by the canopy as a function of an extinction coefficient $(k)$ (see Equation 6):

$f_{1}=1-e^{(-K \cdot L A I)}$

\section{RESULTS AND DISCUSSION}

The irrigation water applied during the growing cycle was equal to $119.8 \mathrm{~mm}$. The total crop water uptake was $102.5 \mathrm{~mm}$, with a maximum value of $3.75 \mathrm{~mm} \mathrm{day}^{-1}$ and an average one of $1.63 \mathrm{~mm}$ day $^{-1}$. The average leaching fraction during the growing cycle was about $20 \%$.

As the terminal buds of the plants were pruned in this experiment to stop the vegetative growth and promote the fruit development, the $L A I$ values fitted well $\left(\mathrm{R}^{2}=0.98\right)$ to a sigmoid Gompertz crop growth curve (See Equation 7):

$$
L A I=1.3275 \cdot e^{-26.05 \cdot e^{-0.1342 \cdot C T T}}
$$

The fitting was performed by the Least Squares method ( $\mathrm{P}$ value $<0,05)$ and it was carried out using the Microsoft Excel Solver. It should be noted that there is a good correlation between the $W U$ and the $L A I$ but, there are no good correlations between the $W U$ and climatic variables (Table 1).

There was a poor relationship between the $W U$ and the incoming radiation under greenhouses in tropical climate conditions opposed to other climatic conditions (FERNÁNDEZ et al. 2010; TA et al. 2011). This fact may be partly explained by the steadiness of the radiation inside the greenhouse due to the low temporal variation of the solar radiation in tropical climates, the high fraction of diffuse radiation due to the high cloudiness of the atmosphere in equatorial areas (SHARMA \& PAL, 1965) and the low transmissivity of the plastic film to the radiation, in general, and to the diffuse radiation in particular.

The experimental daily values of $W U$, the climatic variables and the modelled $L A I$ were used to fit the equation proposed by BAILLE et al. (1994a, b). The fitting was performed by the Least Squares method and it was carried out using the Microsoft Excel Solver. The fitting of the $W U$ values to the Baille equation was not good enough as the coefficient of determination $\left(R^{2}\right)$ was equal to 0.77 . The fitted values of the parameters $A$ and $B$ were $\mathrm{A}=0$ and $\mathrm{B}=2.48$. This fact confirms that the $W U$ was not statistically correlated to the radiation term although it was better correlated to the aerodynamic term. Figure 1 shows the relationship between the measured water uptake (WU) and both the Radiation (a) and Aerodynamic (b) terms.

The results obtained in this research seem to indicate that the transpiration is not controlled by the radiation as energy does not seem to be a limiting factor regarding the transpiration rate. However, as measured indoor radiation is not very high, this fact seems to indicate that there are sensible heat exchanges between the environment and the crop. As evapotranspiration seems to be limited by the water

Table 1 - Correlation coefficients between the daily water uptake of the crop $(W U)$, the air temperature $(T)$ the indoor solar radiation $(R)$, the vapour pressure deficit $(V P D)$ and the leaf area index $(L A I)$.

\begin{tabular}{llllll}
\hline & WU & T & R & VPD & LAI \\
\hline $\mathrm{T}$ & 0.38 & & & & \\
$\mathrm{R}$ & 0.18 & 0.71 & & & \\
$\mathrm{VPD}$ & 0.33 & 0.90 & 0.80 & & \\
LAI & 0.93 & 0.39 & 0.21 & 0.34 & \\
\hline
\end{tabular}




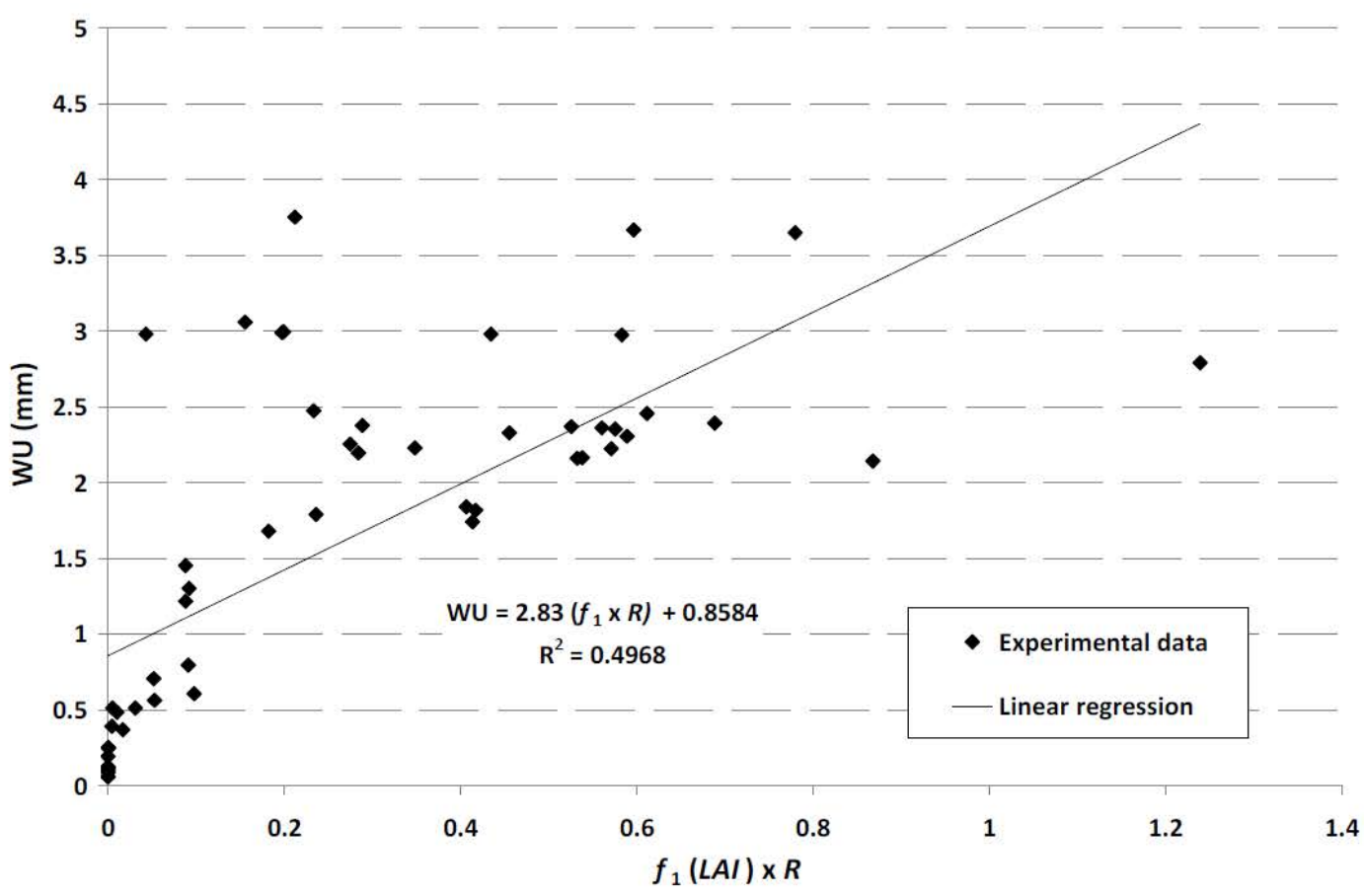

(a)

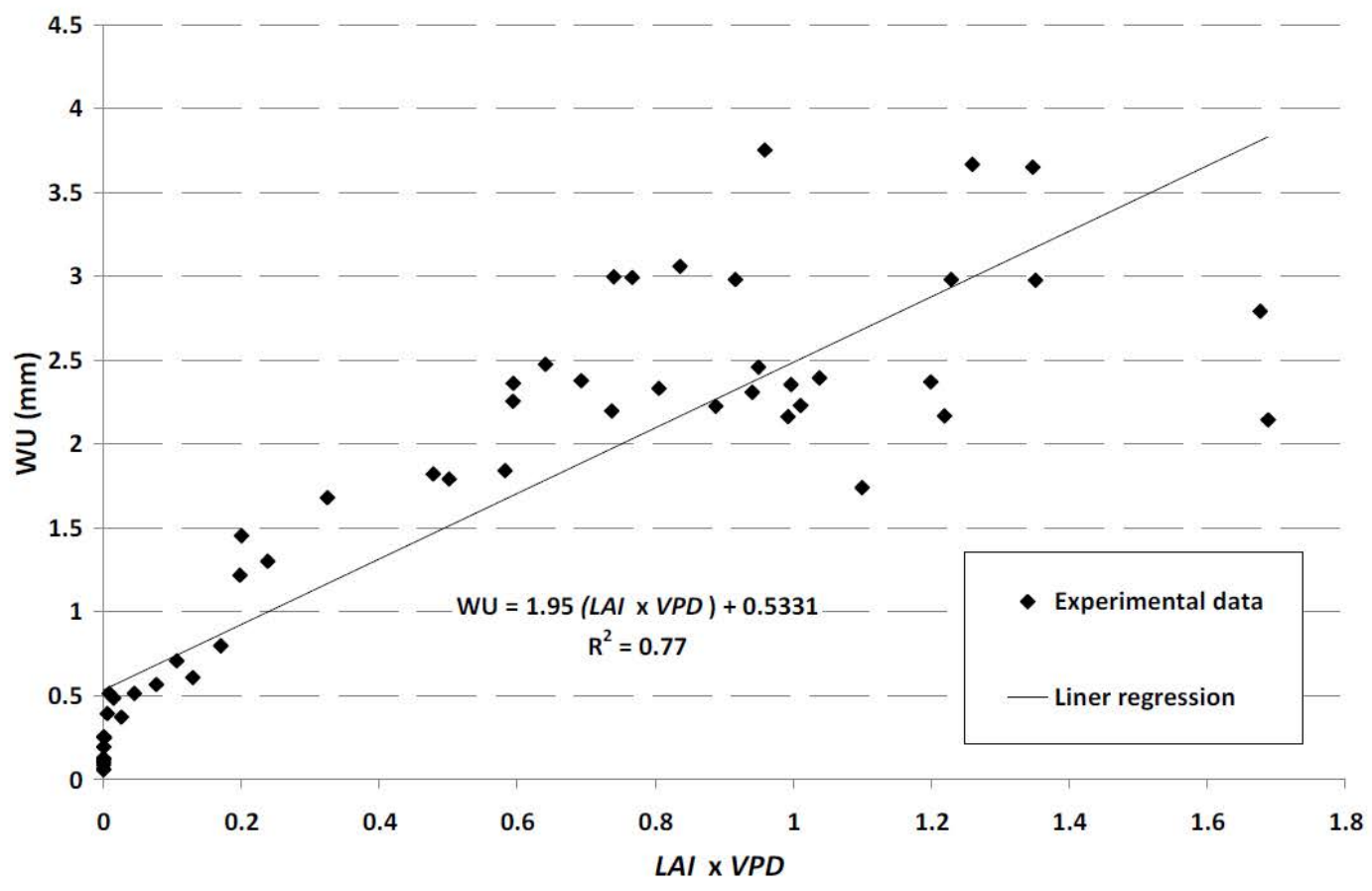

(b)

Figure 1 - Relationship between measured water uptake $(W U)$ and both Radiation $\left(f_{I}(L A I) \times R\right)($ a) and Aerodynamic $(L A I \times V P D)($ b) terms in the Baille equation. 
vapour deficit, the sensible heat in the environment inside the greenhouse increases and an increased flow of sensible heat between air and crop can occur. This heat exchange may also be due to the advective effect caused by the accumulated heat in the air surrounding the greenhouse, in the soil or in the greenhouse structure. These heat exchanges may also happen during the night time as the air temperature remains relatively constant by night. Other research have reported relatively low night time transpiration rates (from 5 to $12 \%$ ) in other climatic conditions (MASUDA et al., 1990). However, it is supposed that the night water uptake rates may result considerably higher in these conditions. This effect should be further investigated in the future.

The Penman-Monteith daily $E T_{o}$ values were calculated for the growing cycle. The $E T_{o}^{o}$ values ranged from 0 to $3.13 \mathrm{~mm}$, with an average values of $1,5 \mathrm{~mm}$. The $K_{c}$ values of the cucumber crop were estimated from the calculated $E T_{o}$ values and the experimental water uptake data. Assuming that WU equals the average $K_{c}$ value was of 1.25 . However, these values were too variable and in same cases abnormally high. This result indicated that the $E T_{o}$ estimation in these specific climatic conditions using the Peman-Monteith formula does not seem to be as satisfactory as expected.

The proposed model to estimate the water uptake of the crop takes into account the observed behavior of the crop throughout its different development stages. Three different periods were distinguished:

1) Phase I: this period includes the establishment, the developmental and vegetative growth and the first flowering as well as the fruit set. $L A I$ values were delimited, ranging from 0 to a specific $L A I_{I}$ value $\left(L A I_{I}=0.75\right)$. During this initial stage, the water uptake is linearly related to the $L A I$. There seems to be a constant transpiration rate per unit $L A I$ and $W U$ can be modelled using the following fitted equation:

$W U=2.93 \cdot L A I+0.22 \quad \forall L A I<0.75 \quad\left(\mathrm{R}^{2}=0.97\right)$

b) Phase II: this stage coincides with the fruit development for $L A I$ values ranging from $L A I_{I}$ to $L A I_{I I}\left(L A I_{I I}=1.1\right)$. During this stage, a constant $W U$ $\left(W U_{I I}=2.4 \mathrm{~mm} \mathrm{day}^{-1}\right)$ was observed. This is due to the lower canopy development during this stage and partial shading of the crop that makes the effective $L A I$ to remain fairly constant:

$$
W U=W U_{I I} \quad \forall 0.75 \leq L A I<1.1
$$

c) Phase III: the third stage coincides with the harvesting phase. During this stage, the $W U$ is highly variable and does correlate well neither with the $L A I$ nor with the climatic variables. The harvests, fall of the leaves, crop ripening, and other unknown factors are likely playing an important role in the behaviour of the crop during this phase. Equation 10 is proposed to model the $W U$ during this phase. This equation results from a weighted average of the value of the $W U$ for the second stage and the adjusted modified Baille equation:

$$
\begin{aligned}
& W U=\left(\frac{L A I-L A I_{I I}}{L A I_{M a x}-L A I_{I I}}\right) \cdot W U_{I I}+ \\
& \left(\frac{L A I_{M a x}-L A I}{L A I_{M a x}-L A I_{I I}}\right)(1.95 \cdot(L A I \cdot V P D)+0.54)
\end{aligned}
$$

Figure 2 demonstrates the experimental values of the $W U$ and the simulated values both for the calibration experiment (year 2011) and for the validation experiment (2014). The $W U$ values fits fairly well to the simulated values in both cases as it is shown in this graph. The overall coefficient of determination $\left(R^{2}\right)$ was equal to 0.93 and 0.89 . These results confirm the validity of the developed model. However, although the overall fit of the model is fairly good, it must be pointed out that the accuracy of the proposed model decreases at the end of the crop cycle. More experimental research should be carried to better understand the factors involved in the water consumption during this period and to improve the accuracy of the model.

\section{CONCLUSION}

An experiment was conducted in order to assess experimentally and to model the crop water consumption of a soilless cucumber crop grown under a plastic greenhouse in specific humid tropical climate conditions. The crop growth in these specific conditions fitted well to sigmoid Gompertz type functions.

Two different combination methods, namely the Penman-Monteith and the Baille equations, were applied to model the measured daily crop water uptake as a function of the indoor climatic variables. However, none of these combination methods were satisfactory due to the poor correlation between the climatic variables and the crop's water uptake $(W U)$. Steadiness of the climatic variables in this specific tropical weather conditions and the effect of the heat exchanges between the environment and the crop 


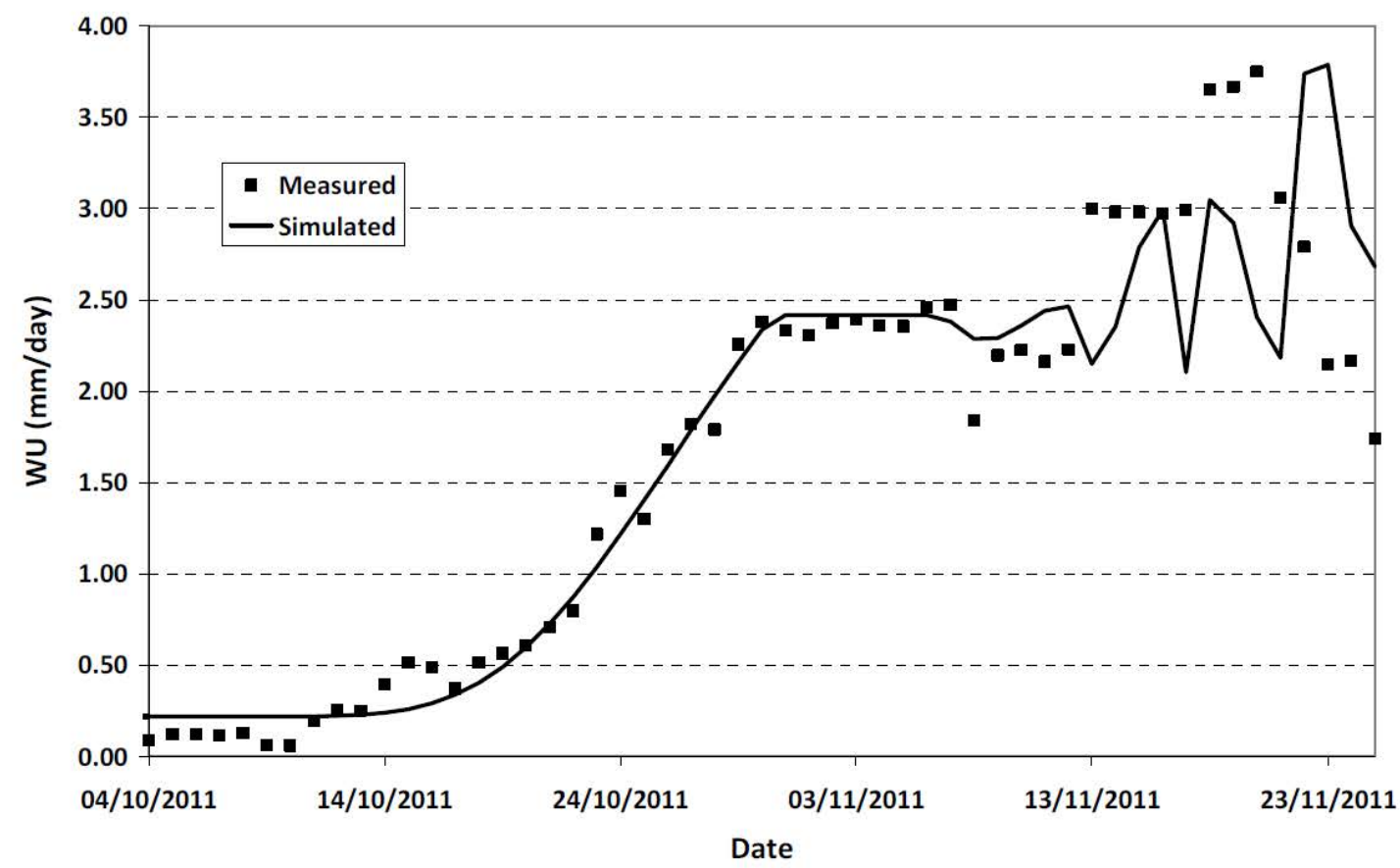

(a)

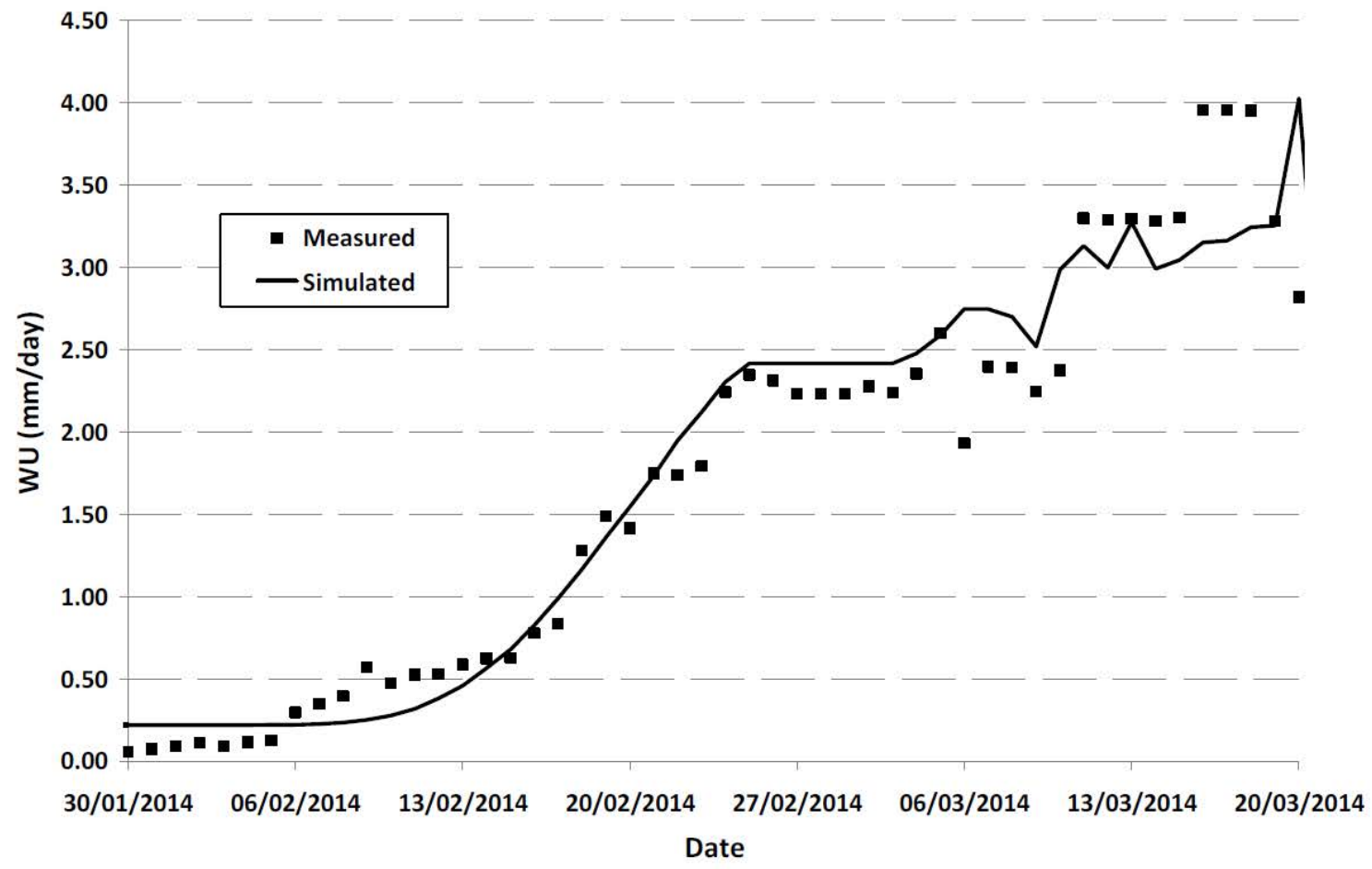

(b)

Figure 2 - Comparison between measured and simulated daily water uptake (WU) of a cucumber crop. First experiment (a), second experiment (b) 
have been highlighted as possible causes of this poor correlation.

A good correlation was reported between the crop's water uptake and the leaf area index (LAI), especially in the early stages of the crop (establishment and vegetative development). After these stages, the $W U$ stabilizes and becomes independent from the $L A I$.

A preliminary model to simulate crop water uptake was proposed and validated using the data obtained in two field experiments. However, more experimental research has to be done in order to develop a more precise water uptake model in these specific conditions.

\section{REFERENCES}

ALLEN, R.G. et al. Crop evapotranspiration: guidelines for computing crop water requirements. Rome: UN-FAO, 1998. 298p. (Irrig Drain. Paper 56).

BAILEY, B. et al. Transpiration of Ficus benjamina: comparison of measurements with predictions of the Penman-Monteith model and a simplified version. Agric For Meteorol, v.65, p.229-243, 1993. Available from: <http://www.sciencedirect.com/science/ article/pii/0168192393900064>. Accessed: Aug. 23, 2015. doi: doi:10.1016/0168-1923(93)90006-4.

BAILLE, M. et al. Microclimate and transpiration of greenhouse rose crops. Agric For Meteorol, v.71, p.83-97,1994a. Available from: <http://ww.sciencedirect.com/science/article/ pii/0168192394901015>. Accessed: Aug. 20, 2015. doi: 10.1016/0168-1923(94)90101-5.

BAILLE M. et al. A simplified model for predicting evapotranspiration rate of nine ornamental species vs climate factors and leaf area. Sci Hort, v.59, n.3-4, p.217-232, 1994b. Available from: <http://www.sciencedirect.com/science/ article/pii/0304423894900159>. Accessed: Aug. 15, 2015. doi: 10.1016/0304-4238(94)90015-9.

CARMASSI, G. et al. An aggregated model for water requirements of greenhouse tomato grown in closed rockwool culture with saline water. Agric Water Manage, v.88, p.73-82, 2007. Available from: $<$ http://www.sciencedirect.com/science/article/pii/ S0378377406002575>. Accessed: Aug. 10, 2015. doi: 10.1016/j. agwat.2006.10.002.

CONFALONE, A.E. et al. Expolinear model on soybean growth in Argentina and Brazil. Ciênc Rural, v.40, p.10091016, 2010. Available from: <http://www.scielo.br/scielo. php? $\mathrm{script}=\mathrm{sci}$ arttext\&pid $=\mathrm{S} 0103-84782010000500002>$. Accessed: Aug. 26, 2015. doi: 10.1590/S010384782010000500002 .

COSTA, P.C. et al. Produção de pepino de plantas enxertadas cultivadas em soluções nutritivas com diferentes teores de potássio. Hortic Bras, v.19, n.3, p.207-209, 2.001. Available from: $<$ http://www.scielo.br/scielo.php?script=sci arttext\&pid=S0102-05362001000300010>. Accessed: Aug. 25, 2015. doi: 10.1590/S0102-05362001000300010.
FERNÁNDEZ, M.D. et al. Measurement and estimation of plastic greenhouse reference evapotranspiration in a Mediterranean climate. Irrig Sci, v.28, p.497-509, 2010. Available from: $<$ http:// link.springer.com/article/10.1007/s00271-010-0210-z>. Accessed: Aug. 16, 2015. doi: 10.1007/s00271-010-0210-z.

GOMPERTZ, B. On the nature of the function expressive of the law of human mortality, and on a new mode of determining the value of life contingencies. Phil Trans Roy Soc London, v.123, p.513-585, 1832 .

HSIAO, T.C. et al. A systematic and quantitative approach to improve water use efficiency in agriculture. Irrig Sci, v.25, n.3, p.209-231, 2007. Available from: <http://link.springer.com/ article/10.1007/s00271-007-0063-2>. Accessed: Aug. 6, 2015. doi: 10.1007/s00271-007-0063-2.

INEC. Encuesta de superficie y producción agropecuaria continua ESPAC-2013. 2014. Available from: <http://www. ecuadorencifras.gob.ec/estadisticas-agropecuarias-2>. Accessed: Jul. 20, 2015.

JOLLIET, O.; BAILEY, B.J. The effect of climate on tomato transpiration in greenhouse: measurements and models comparisons. Agric For Meteorol, v.58, p.43-63, 1992. Available from: $\quad<$ http://www.sciencedirect.com/science/ article/pii/016819239290110P $>$. Accessed: Jul. 20, 2015. doi: 10.1016/0168-1923(92)90110-P.

KATSOULAS, N. et al. Effect of misting on transpiration and conductances of a greenhouse rose canopy. Agr Forest Meteorol, v.106, p.233-247, 2001. Available from: <http://www.sciencedirect.com/science/article/pii/ S0168192300002112>. Accessed: Aug. 11, 2015. doi: 10.1016/ S0168-1923(00)00211-2

MASUDA, M. et al. Uptake of water and minerals during the day and the night in tomato and cucumber plants. J Jpn Soc Hortic Sci, v.58, n.4, p.951-957, 1990. Available from: <https://www.jstage. jst.go.jp/article/jjshs1925/58/4/58_4_951/_article>. Accessed: Aug. 21, 2015. doi: 10.2503/jjshs.58.951

MEDRANO, E.P. et al. Evaluation and modeling of greenhouse cucumber-crop transpiration under high and low radiation conditions. Sci Hort, v.105, p.163-175, 2005. Available from: $<$ http://www.sciencedirect.com/science/article/pii/ S0304423805000543>. Accessed: Aug. 13, 2015. doi: 10.1016/j. scienta.2005.01.024

ORGAZ, F. et al. Evapotranspiration of horticultural crops in unheated plastic greenhouses. Agric Water Manage, v.72, p.8196, 2005. Available from: <http://www.sciencedirect.com/science/ article/pii/S0378377404002306>. Accessed: Aug. 20, 2015. doi: 10.1016/j.agwat.2004.09.010.

SHARMA, M.R.; PAL, R.S. Interrelationships between total, direct, and diffuse solar radiation in the tropics. Sol Energy, v.9, p.183-192, 1965. Available from: $<\mathrm{http}: / / \mathrm{www}$.sciencedirect.com/science/article/ pii/0038092X65900459>. Accessed: Aug. 20, 2015. doi: 10.1016/0038-092X(65)90045-9.

SHAW, N.L.; CANTLIFFE, D.J. Hydroponic greenhouse production of "Baby" squash: selection of suitable squash types and cultivars. Hort-Tech, v.15, n.3, p.722-728, 2005. 
STANGHELLINI, C. Transpiration of greenhouse crops: an aid to climate management. 1987. 150f. $\mathrm{PhD}$ Thesis. Wageningen.

STEDUTO, P. et al. Crop yield response to water. FAO. Rome: FAO, 2012. 500p. (Irrig Drain Paper 66).

TA, T.H. et al. Modeling of transpiration of paprika (Capsicum annuиm L.) plants based on radiation and leaf area index in soilless culture. Hort Environ Biotechnol, v.52, n.3, p.265-269, 2011. Available from: $<$ http://1ink.springer.com/article/10.1007/s 13580 -
011-0216-3>. Accessed: Aug. 20, 2015. doi: 10.1007/ s 13580-011-0216-3

VASCO, M.R. El cultivo del pepino bajo invernadero. In: CAMACHO, F.F. (Ed.). Técnicas de producción en cultivos protegidos. Cajamar, Almería, España: Caja Rural Intermediterránea, 2003. p.691-722.

YAGHI, T. et al. Cucumber (Cucumis sativus, L.) water use efficiency (WUE) under plastic mulch and drip irrigation. Agric Water Manage, v.128, p.149-157, 2013. Available from: <http:// www.sciencedirect.com/science/article/pii/S0378377413001467>. Accessed: Aug. 22, 2015. doi: 10.1016/j.agwat.2013.06.002. 